\title{
Evidence of Language Contact: Source Prepositional Phrases in Taiwanese Southern Min
}

\author{
Yen-Ting Lin*
}

LSA Annual Meeting, Portland, January 8-12, 2015

1. Introduction. This paper presents a new corpus-based study on the distributional pattern of source prepositional phrases in Taiwanese Southern Min (TSM) as evidence of contact with Austronesian languages. Due to its unique contact history and geographic proximity to Austronesian territories, Taiwan is a natural laboratory for studying substrate influence. However, the literature regarding the influence of the Austronesian languages on the TSM has remained scarce. This study begins with the constituency of the source PPs in TSM and their positional variation with respect to the verb and utilizes a synchronic corpus to examine the dominant pattern. The results show that this unique [V-PP] pattern is new and infrequent in terms of type frequency, suggesting a possible contact with Austronesian languages. The following explanation provides historical records regarding the bilingual environment during the $16-18^{\text {th }}$ centuries and the basic word order and geographical distribution of Austronesian languages. This also echoes the theory of language contact: while contact-induced changes affect the less powerful/prestigious language, effects also occur in the inverse direction due to imperfect second language acquisition (LaPolla 2001, Chappell 2006).

\section{Further details.}

2.1 THE CONSTITUENCY OF SOURCE PPS IN TSM. This study focuses on TSM, a spoken variety of the Southern Min dialects under Sinitic language family. The source PPs in TSM are marked by àn 'from/via' and tui/uì 'from/via/towards'. The definition of source/route/directional/goal follows Jackendoff's (1983: 170-174; 1990: 91-95) treatment of path semantics in his Conceptual Semantics theory. For instance, the PP in the sentence John walked from the store is classified as expressing a source function: the place that John walked away from. The preposition àn 'from/via' is shared among most Southern Min dialects. Secondly, tuìuì, 'from/via/towards', dating back to the historical text Li Jing Ji (1566) in Southeast China, has only been preserved in TSM. Due to its multiple semantic functions, it can mark a directional, a route, or a source NP, depending on the context and collocation.

2.1.1 THE ORDER OF THE SOURCE PP AND VERB IN TSM. As a member of VO languages, Sinitic languages ${ }^{1}$ are known for having a typologically disharmonic [PP-V] pattern in terms of the distribution of the source PP. Following this feature, the distribution of the source PP and verb in TSM display a [PP-V] pattern, as shown in (1). The SOURCE PPs, àn tó-ui 'from/via where' in (1a) and tuì tôo-su-kuán 'from/via/towards the library' in (1b), both precede the verb kiânn 'to go'. Note that the two morphemes lâi/khì 'to come/go' are treated as directional markers, since both only indicate the speaker's perspective and do not determine the semantic roles of the spatial NP.

\footnotetext{
* I would like to thank Dr. Matthew Dryer, Dr. Jürgen Bohnemeyer, and Dr. Jeff Good for their valuable comments on the earlier draft. I thank my colleagues Alice Mitchell and Derry Moore for additional comments. I am very grateful for the detailed comments from an anonymous reviewer. All the remaining errors are mine.

Author: Yen-Ting Lin, University at Buffalo (yentingl@ buffalo.edu)

${ }^{1}$ The Chinese grammars consulted in this study are Mandarin Chinese (Li and Thompson) Shanghai Wu (Zhu 2006), Xiang (Wu 2005), Fuzhou (Li 2002), and Cantonese (Matthews and Yip 1994).
} 


lí àn tó-uī kiânn
2 sg from/via where go
'Where are you from/via?'

lâi/khì ?

come/go

lin tuì tôo-su-kuán kiânn
$2 \mathrm{pl}$ from/via/towards library go lâi/khì
'You (pl.) walked from/via/towards the library.'

2.2 NEW EVIDENCE FOR THE [V-PP] PATTERN IN TSM. Empirical observations, including new corpus evidence, reveal a previously unattested pattern in the source PPs in TSM, pointing to possible contact with Austronesian languages in Taiwan. This [V-PP] pattern has never been reported in any given literature and is typologically exceptional within Sinitic languages. In terms of type frequency, the corpus results suggest that this pattern is rare and infrequent and is treated as a novelty.

2.2.1 EMPIRICAL OBSERVATIONS. The source PPs in TSM do allow a [V-PP] pattern, which has never been reported in the literature. The examples in (2) illustrate the [V-PP] pattern: both source PPs follow the verb. The two orders are used interchangeably with the same interpretation, based on native speaker judgments ${ }^{2}$. For source prepositions in TSM, there are no apparent selectional restrictions of the verbs that could account for the variation. It does not appear to be the case that some verbs prefer [PP-V] and others [V-PP].

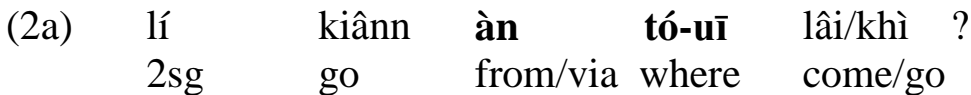

'Where are you from/via?'

$\begin{array}{lllll}\text { lin } & \text { kiânn } & \text { tuì } & \text { tôo-su-kuán } & \text { lâi/khi } \\ \text { 2PL } & \text { go } & \text { via/towards } & \text { library } & \text { come/go } \\ \text { 'You (pl.) } & \text { walked from/via/towards the library.' }\end{array}$

The [V-PP] pattern has not been observed historically in any other Southern Min dialects or Sinitic languages and is distinctively rare within its language family, suggesting possible contact with Austronesian languages.

2.2.2 A CORPUS-BASED ANALYSIS. This study uses a TSM concordance, developed by Iûnn (2003, as a database to capture the dominant pattern of source PP and verb in $\mathrm{TSM}^{3}$. The coding analysis was performed manually to eliminate the irrelevant usages and further examine the semantic roles of the spatial NPs. In Table 1, even though both source PP types allow flexible orders, the [PP-V] pattern is preferred as the dominant pattern: the àn-phrases display a strong [PP-V] tendency (94\% of tokens), and the tuì-phrases occur more frequently with [PP-V] order (about 65\%), and, with the pattern of [V-PP], the spatial NPs are classified as Source in $8 \%$ (2) of the instances.

\footnotetext{
${ }^{2}$ Future research will have to establish whether the choice between the two orders is impacted by processing factors.

${ }^{3}$ This corpus includes Han characters and POJ texts (5816250 syllables), which contains a broad variety of oral an written genres to enhance the validity. Péh-ōe-jī, abbreviated as POJ, literally vernacular writing, also known as Church Romanization, is an orthography used to write variants of Southern Min, a Chinese language or dialect, particularly Taiwanese and Amoy Hokkien. POJ is developed by Western missionaries working in Southeast Asia in the $19^{\text {th }}$ century.
} 


\begin{tabular}{|c|c|c|c|}
\hline Source Prepositions in TSM & PP-V & V-PP & total \\
\hline from/via & $94 \%(60)$ & $6 \%(4)$ & $100 \%(64)$ \\
\hline from/via/towards & $65 \%(36)$ & $35 \%(19)$ & $100 \%(55)$ \\
\hline
\end{tabular}

Table 1 The distribution of the two orders of source PP and verb in the TSM corpus

2.3 [V-PP] BORROWED FROM AUSTRONESIAN LANGUAGES. The emergence of the [V-PP] order may be attributed to contact with Austronesian languages, based on their word order and contact history with Southern Min in Taiwan. Austronesian languages are widely known for having a rigid predicate-initial pattern; among them, Atayal, Rukai, Puyuma, and Siraya clearly exhibit a [V-PP] pattern (Adelaar 2011; Dryer, p.c.). In Siraya, the ablative preposition măka- is used to mark the spatial NP ki kä̈wlung 'the man' (Adelaar 2011: 87). As shown in (3), the verb arang 'to leave' precedes the Source PP măka-rbo ki kaäwlung 'from/out of the man'.

$$
\begin{array}{llll}
\begin{array}{l}
\text { Siraya (Adelaar 2011: 84) } \\
\text { ru } \quad \mathrm{d}<\mathrm{m}>\text { arang- }
\end{array} & \mathrm{al}=\text { ato } & \text { măka-rbo } & \text { ki kaäwlung } \\
\text { when }<\mathrm{AO} 3>\text { leave- } & \mathrm{SJ}=\mathrm{PRF} & \text { AO4.come.from-inside } & \text { DF person }
\end{array}
$$

\section{ki kaäwlung}

ta Iupan ka ăsi ma-tikanax

NOM spirit LK NEG AO1-clean

'When the unclean spirit is gone out of a man.'

The early distribution of the Austronesian languages, as documented by Blust (1999), illustrated that the Southwest Taiwan, where Siraya was spoken, is now occupied by the majority of the TSM speakers. As pointed out by Prof. Li, Jen-kuei, intensive contact with TSM in the $18^{\text {th }}$ century accelerated the extinction of Siraya (Adelaar 2011: 70). The distribution and subsequent extinction of the Austronesian languages makes the language contact argument more plausible.

2.4 EARLY BILINGUALISM IN TAIWAN. The early bilingual environment in Taiwan proves that this [V-PP] pattern might be the result of imperfect second language acquisition of Austronesian during the process of sinocization due to the lack of native Southern Min speakers. The language contact began through intermarriage and education. As early as the $16^{\text {th }}$ century, the Fujianese migrations had gradually brought in Southern Min Chinese men, engaging in coastal trade and exchange business (Shepherd 1993: 35). Even though the early immigrants were fewer in numbers, they had gained more control over the wealth and power and treated themselves as social elites. The Chinese government had set many harsh restrictions for the family migrations; therefore, only Chinese bachelors were eligible for migration. This restriction had increased the demand of Southern Min men for Austronesian wives. The union with Southern Min men was also favored by Austronesian families because these men were more used to agricultural work and added political and economic values to these families. The children of these intermarriages were thus raised in a multilingual/multicultural setting. The young Austronesian-Southern Min bilinguals were expected to raise their social status within and even outside the village through speaking a second language. Later in the $18^{\text {th }}$ century, the historical texts illustrated that when the influx of Chinese had made China become politically and economically important for Austronesians, more intensive sinocization through education and intermarriage with Chinese men had accelerated the acquisition of Southern Min by native 
speakers of Austronesian languages (Shepherd 1993: 376-90). For instance, the proficiency of Southern Min was an indication of the degree of sinocization for Austonesians and there was a great variation of sinocization within the Austronesian families. From the above historical documentation, the population size of the Southern Min immigrants was relatively small before $18^{\text {th }}$ century in contrast to that of the Austronesians. During the process of sinocization, lack of native Southern Min speakers might result in imperfect second language learning for Austronesians and further change the word order of TSM.

3. Theoretical Significance. This is the first study of the early substrate influence of Austronesian languages on TSM in terms of word order typology. The positional variation of SOURCE PPs in TSM represents an unusual typological pattern within its own language family and provides evidence of contact. It also provides evidence for a process of contact-induced change during which the structure of the target language may be changed due to imperfect second language acquisition. The corpus study presented here illustrates the explanatory power of combining areal and diachronic approaches to variation in synchronic data (Dryer 2003, 2006).

\section{References}

Adelaar, K. Alexander (2011). Siraya: Retrieving the Phonology, Grammar and Lexicon of a Dormant Formosan Language. Berlin: De Gruyter Mouton

Blust, Robert (1999). Subgrouping, circularity and extinction: some issues in Austronesian comparative linguistics". In Zeitoun, Elizabeth; Li, Jen-kuei. Selected papers from the Eighth International Conference on Austronesian Linguistics (Taipei: Academia Sinica).

Chappell, H. (2006). Language Contact and Areal Diffusion in Sinitic Languages. In: Alexandra Aikhenvald \& RMW Dixon (eds.) Areal diffusion and genetic inheritance: problems for typology and genetic affiliation. Oxford: Oxford University Press.

Dryer, Matthew S. (2003). Word order in Sino-Tibetan languages from a typological and geographical perspective. In Sino-Tibetan Languages. (eds) Graham Thurgood and Randy LaPolla. Richmond: Curzon Press

Dryer, Matthew S. (2006). Descriptive theories, explanatory theories, and basic linguistic theory. In Catching Language: Issues in Grammar Writing. (eds) Felix Ameka, Alan Dench, and Nicholas Evans. Berlin: Mouton de Gruyter.

Iûnn, Ún-giân (2003). Tai-gu-bun gu-su kiam-sek. [Taiwanese Concordance]. (Available online at http://ip194097.ntcu.edu.tw/tg/concordance/form.asp, Accessed on 2014-07-27)

Jackendoff, R. (1983). Semantics and cognition. Cambridge, MA: MIT Press.

Jackendoff, R. (1990). Semantic structures. Cambridge, MA: MIT Press.

LaPolla, Randy. (2001). The Role of Migration and Language Contact in the Development of the Sino-Tibetan Language Family. In Areal Diffusion and Genetic Inheritance: Problems in Comparative Linguistics (eds) Alexandra Y. Aikhenvald and R. M. W. Dixon

Li, Charles N. and Sandra Thompson. (1981). Mandarin Chinese: A Functional Reference Grammar. University of California Press. London, England.

Li, Zhuqing. (2002). Fuzhou Phonology and Grammar. Dunwoody Press

Matthews, Stephen and Virginia Yip. (1994). Cantonese: A Comprehensive Grammar. Routledge, London.

Shepherd, John R. (1993). Statecraft and Political Economy on the Taiwan Frontier, 1600-1800. Stanford, California: Stanford University Press.

Wu, Yunji. (2011). A Synchronic and Diachronic Study of the Grammar of the Chinese Xiang Dialects. Trends in Linguistics. Studies and Monographs [TiLSM] 162. Berlin, Boston: De Gruyter Mouton

Zhu, Xiaonong. (2006). A Grammar of Shanghai Wu. LINCOM studies in Asian linguistics 66. Munich: LINCOM Europa 